\title{
Rethinking the Notion of 'Value' in Global Value Chains Analysis: A Decolonial Political Economy Perspective
}

Sofa Gradin

School of Politics and International Relations

Queen Mary University of London, United Kingdom

Please see full and correct version in Competition and Change vol 20 issue 5 (2016)

\begin{abstract}
This article critically examines how the concept of value has been understood in Global Value Chains (GVC) analysis. In particular, it is argued that the GVC literature has largely overlooked the political and contested nature of the concept by relying on conventional understandings of value borrowed from mainstream Economics and Business Studies. This article reconsiders the notion of value and its role within GVC analysis using insights offered by decolonial and critical authors. It argues that value should be understood not only as narrow pecuniary gains but also as a broader philosophical question regarding the justice and purpose of productive activity. It proposes the new concept of 'voice upgrade' as a tool to appreciate the extent to which different formal and informal institutional settings in global value chains allow for democratic negotiations about value.
\end{abstract}




\section{Introduction}

This article critically engages with the way in which the concept of value has been understood in Global Value Chains (GVC) analysis. For a literature so concerned with global distribution and production of value, there is a dearth of critical analysis of how the concept should be understood (Taylor, 2010). As a result, GVC analysts have relied too readily on conventional understandings of value borrowed from mainstream economics and Business Studies literature, which may be incompatible with anticolonial and egalitarian development aims.

This article begins by outlining key insights from the decolonial political economy literature and proceeds to apply them to the treatment of value in GVC analysis. The first of these insights is a rejection of economism - that is, the view that economics is a distinct and technical science as opposed to an acknowledgement that economics is something inherently political (Blaney and Inayatullah, 2010; Zein-Elabdin and Charusheela, 2004). Defining value, therefore, is more than a technical scientific exercise. The second insight is a rejection of totalising narratives, and in particular the assumption that Western or modern paradigms of knowledge should be the only authoritative ones (Mignolo, 2011). This draws attention to new issues. What GVC analysts call 'economic upgrade' can to some extent counteract the colonial division of labour, whereby Northern, or 'core', regions carry out higher-skilled, higher-tech and higher-return productive tasks with the opposite the case for Southern, or 'peripheral' regions and countries (Dos Santos, 1970). However, this notion of economic upgrade also imposes Northern notions of success and development on the South thereby constraining other options. This article suggests that engaging in critical discussions about value is a key opportunity for grappling with this issue.

The argument posited here suggests that value should also be understood as a broader philosophical concept concerning the justice and purpose of human productive activity (Graeber, 2001; Henderson, 2013). Whether we see value as labour time (Marx, 2015 [1887]; Harvey, 2010) or as pecuniary rewards (e.g. Porter, 1985), the question is raised as to how work should be divided up between people, how remuneration and resources should be distributed and what progress or development would look like. As authors critical of capitalism and of prevalent conceptions of value in the GVC literature have pointed out, labour is key to understanding value and value chain upgrade, not only because it is the ultimate source of value, but also because of its political agency (Rainnie et al., 2011). GVC analysis must pay greater attention to political struggles throughout the value chain.

The article proposes the addition of the new concept of 'voice upgrade' to the GVC toolkit as a means of appreciating the extent to which people in a value chain can participate in decisions around these fundamental questions of value. Further, it concerns the ways in which formal and informal institutional settings within and between firms in GVCs allow for democratic negotiations. 
The next section will briefly outline the theoretical underpinnings of a decolonial critique of the treatment of value in GVCs. Section 3 provides an overview of GVC analysis, and section 4 explores the way in which GVC and related literatures have treated the concept of value. Section 5 focuses on the contribution of critical discussions (usually from a broadly Marxist perspective) about value in GVC literature. The penultimate section outlines the notion of voice upgrade, before concluding.

\section{Critical and decolonial political economy}

This article seeks to repoliticise the notion of value in GVC analysis. It does so by drawing on two analytical insights from critical and decolonial literatures: firstly the rejection of economism, and secondly the rejection of totalising narratives (Mignolo and Escobar, 2010; Mignolo, 2011; Collins, 1990). Instead, economics is seen as implicitly incorporating politics, and the global economy is seen as consisting of a variety of economies (Gibson-Graham, 2006a).

Economism is the assumption that economics is separate from other social forces (see Gasper, 2004). In the last century, the discipline of economics has become delineated as distinct from other social science and humanities subjects. Economics, it is often assumed, stands outside of political and moral negotiations (Burnham, 1999; Granovetter, 1985). This is a relatively new development as any classical and traditional authors were interdisciplinary. For example, Adam Smith's The Wealth of Nations (1976 [1776]) was written as an addition to his earlier work on moral philosophy, The Theory of Moral Sentiments. J.S. Mill was a moral philosopher. The writings of Karl Marx stress the social and power-laden nature of seemingly neutral economic interactions. Only in the past century have the moral-political aspects of economics been given less attention. What once were writings on big issues such as questions of justice have largely become interpreted as writings of objective and universal economic truth (Blaney and Inayatullah, 2010; Hirschman, 1977; Pocock, 1985).

Feminist geographers J. K. Gibson-Graham consider the affective and emotional foundations of any theory (Schmitt, 2010). '[I]t is possible that the most crucial aspect of our thinking is the emotional orientation we bring to it' (Gibson-Graham, 2006b: xxix). The philosophical question of where theories are deduced from (whether from axioms, emotions, god or discourse), is made invisible in mainstream economics. If the lid on the assumptions underlying neoclassical economics is lifted, we generally find competitive individuals acting in their own short-term interest; the homo economicus (Gibson-Graham, 2006a). These normative values arguably echo those of Western 'hegemonic masculinity' (described in Kimmel 1994). That humans are inherently competitive, selfinterested and short-sighted is far from a universal truth, and debates around the 'true' nature of 
humans remain deeply political. In other words, when we abandon the assumptions economics is a universal science, the economic collapses into the political (Davies, 2012).

As a part of economism, the concept of value has been given an increasingly distinctly economic meaning in the last century. While earlier thinkers linked the concept of value to ethics and politics (Aristotle, 2010), it is used as a strictly technical term within economic science. As will be elaborated below, recent critical voices have started to question prevalent conceptions of value in the GVC literature.

A decolonial critique of totalism has been developed by Quijano (2007) and Mignolo (2011). A totalising ontological narrative implies that Western rationality is the only mode of knowledge that exists or is valid, which in turn is linked to the colonial worldview that Western modern or postmodern societies are the centre of the world and constitute progress (Mignolo, 2007). Mignolo argues that totalism has 'authorized its promoter and defender to disregard, marginalize, ignore, deprecate, reprove, rebuke, attack all knowledge that didn't obey the rules and principles of the (post)modern matrix of knowledge' (2011: 111). That is to say, Western science, including economics in particular, has been constructed as part of a colonial project to exclude non-Western epistemologies and construct Western lifestyles as hegemonic. This enables Western academics to universalise and render unquestionable a set of views that are a result of political struggles.

Questioning totalising narratives of economy leads to the question of whether capitalist relations are the only, or even main, form of economic relations (Gibson-Graham, 2008). Rather than assume the omnipresence, inevitability and desirability of capitalist relations, a rejection of totalism opens the possibility of multiple types of economies. In turn this opens up the possibility of multiple understandings of value, which has significant implications for GVC analysis.

\section{Global Value Chains analysis}

Global Value Chains analysis is a school of thought with growing influence in the development industry (Ramiro Fernández, 2015). Emerging in the late 1990s and early 2000s, this literature draws on Dependency Theory and its focus on the global division of labour established under European colonialism. It focuses particularly on the way in which materially rich regions perform productive tasks that require higher technology and more initial investment but that yield much higher earnings, while materially poor regions perform tasks that are lower-paid and lower-skilled (Dos Santos, 1970; Wallerstein, 1974).

GVC analysis studies the division of labour within each value chain. For example, looking at the specific value chain of coffee, a GVC analyst might trace the division of labour between firms: 
those who plant, grow and harvest the beans; those who transport the beans at various stages; those who blend and roast it; design and manufacture packaging; retail it; deal with any waste and offer post-retail customer services (Daviron and Ponte, 2005: 54-55). The task is to look at power relationships within chains. Economic aspects of such relationships concern the extent to which different nodes in the chain capture value, while organisational aspects involve decision making in the chain and who has access to key information and infrastructures (Bolwig et al., 2010: 174; Trienekens, 2011).

In a path-breaking 1994 book, Gary Gereffi, who has been credited as the main co-founder of GVC analysis (or in his terms at the time, Global Commodity Chains analysis, more of which below), listed some key areas of interest in analysing value chains (1994: 96-97). Firstly, tracking the 'inputoutput structure', or in other words, analysing what materials, labour, tools and processes go into making a product and how value-added is distributed along this input-output structure. Secondly, mapping the 'territoriality' refers to the geographical locations of different inputs in the value chain. This enables an understanding of which regions in the global economy carry out higher value-added tasks. Thirdly, Gereffi introduces the notion of 'governance structure' which looks at how decisions are made in a value chain (1994) as interactions within a chain do not to occur 'spontaneously, automatically or even systematically' (Gibbon et al., 2008: 319). One actor in the value chain often plays a co-ordinating role, making chain-wide decisions about what is to be produced, by whom, how, by when, and at what cost (Morrison et al., 2008). The GVC literature has developed a typology of overlapping, but discernible governance styles (Gereffi et al. 2005) that include market dominated modes (where different firms in a value chain have no forward agreement or commitment to each other); network modes (where there is more co-ordination between firms) and hierarchical modes (where a lead firm organises the entire value chain in-house thereby controlling every link in the chain). In a later contribution Gereffi added a fourth analytical concern: the ways in which the institutional context in different countries, localities or sectors might affect global value chains (1995). This can range from formal laws, to governmental industrialisation policies, to less formal social arrangements and conventions.

The central concern in Global Value Chains analysis is tracing where the value-added is contributed and how its distribution can be explained. For GVC analysts, the aim improving the gains of producers in the global South comes through economic upgrading and social upgrading (Barrientos et al., 2011). Economic upgrading means that a firm comes to capture more value-added, whether through exporting products that require higher skilled and higher paid labour (for example clothes designed in-house rather than made to others' specifications), more luxurious or higher quality products, higher volumes of product or more efficiently produced products (Humphrey and Schmitz, 2002). Social upgrading means that workers receive better working conditions, for example higher pay, better hours, more job security, better health-and-safety standards, reductions in discrimination, etc (Barrientos et al., 2011). 
There are many ways in which a firm can upgrade economically. Humphrey and Schmitz (2002) were the first to develop an extensive classification, distinguishing analytically between four, separate, but sometimes overlapping, types of economic upgrade:

process upgrading (making a firm's existing production process more efficient to yield higher returns)

product upgrading (making more advanced and expensive products)

functional upgrading (extending a firm's productive abilities to perform more functions above or below one's position in the value chain. For example, acquiring the ability to roast coffee as well as to grow the beans)

inter-sectoral upgrading (using a firm's capacities in the production of one product to move into the production of another).

Since this original typology was proposed the list has been expanded upon to include; delivering larger volumes (even of lower quality), matching standards and certifications, delivering on logistics and lead times, getting better paid for the same product (for example, fair trade) (Gibbon, 2001; Gibbon and Ponte, 2005; Ponte, 2009)

(Bolwig et al., $2010: 177$ )

The concept of social upgrading is a more recent addition to the literature and was first introduced when the Capturing the Gains research project made it a central analytical device (Milberg and Winkler, 2010; Barrientos et al., 2011). Before this, a small minority of GVC analyses had studied the impact of economic upgrading on workers, although they had done so without a unified analytical framework (Anker et al., 2002; Herod, 2001). Some of these studies took cues from the ILO's Decent Work Agenda. Social upgrading is about 'enhanc[ing] the quality of [...] employment' (Barrientos et al., 2011: 324). However, as Barrientos points out this may not flow automatically from economic upgrading as a firm could, for example, choose to lower its workers' wages in order to capture more value-added.

\section{Value in chain analysis frameworks}

The argument of this article is that Global Value Chains (GVC) analysis has lacked sufficiently critical analysis of the concept of value, and that this literature would benefit from seeing beyond economistic and totalising interpretations of the concept. This section briefly reviews the treatment of value in GVC and other related literatures. 
Although GVC is the most influential type of chains analysis perspective, there are several other frameworks in its family. These perspectives have developed, to some extent, chronologically from Global Commodity Chains to Global Value Chains, via Global Production Networks and others. These perspectives could be understood as different but similar successors to decolonial political economy projects such as Dependency Theory and World Systems Theory (Bair, 2009). To see their development as one of strictly successive schools of thought is, however, too simplistic (Ibid.).

Global Commodity Chains (GCC) was the phrase used by Gary Gereffi et al. (1994) in their initial and foundational conception of the chains analysis framework - although the concept of commodity chains had already been used by Terence Hopkins and Immanuel Wallerstein. The GCC framework was designed to study the production and trading of commodities, most typically primary agricultural products or basic manufactureds such as semi-processed food or textiles (Bair, 2009). This framework provided a way to pinpoint how the global division of labour - and therefore the distribution of rewards - took its expression in specific commodity chains, and how this affected people's welfare in different localities. From the start, GCC highlighted the notion of value-added, studying the ways in which the production of high-value, as opposed to low-value, products affected the wealth - and prospects for future increases in wealth - of different firms. High-value products are in this literature understood as products that require higher skills in their production, and that offer higher pecuniary returns. As Appelbaum et al. (1994: 191) put it:

Following Gereffi (1992), we operationalize value-added as the per-unit export value of the final product. Other things being equal, we reason, a more expensive commodity reflects high-skilled production (as well as greater opportunity for profit-taking) than a less expensive one.

Similarly, in an earlier article Gereffi and Korzeniewicz wrote of value in terms of economic rents (1990) commonly understood in terms of pecuniary income (Kaplinsky, 1998).

In this literature, therefore, value can be interpreted as being related to price, profitability, and highskilled labour. This is somewhat of a departure both from common interpretations of Marxist labour theory/ies of value, and from many Dependency Theorists' focus on industrial capabilities and selfsufficiency. This draws on Business Studies literature, and in particular Michael Porter's influential value chain framework, designed to help businesses increase productivity and profit (Porter, 1985). Porter understood value as 'what buyers are willing to pay for a product or service' (:xvi and 3), which would be measured by 'total revenue' (:38).

The GVC perspective was developed to better suit the analysis of more complex chains, and chains that do not necessarily trade in commodities (Global Value Chains Initiative, 2016). Perhaps the most important difference between GVC and GCC is that the former draws to a somewhat greater extent on sociology and political science, and places a greater emphasis on power (Sturgeon, 2009). '[T] he term value both captured the concept of "value-added" [...] and focused attention on the 
main source of economic development: the application of human effort, often amplified by machines, to generate returns on invested capital' (Sturgeon, 2009: 117, emphasis in original). This should be interpreted as a nod to Marxist labour theory of value, but also as a broader shift towards recognising social and political aspects of economic behaviour.

GVC analysis opens up a space for authors who question the extent to which the profit-motive takes precedence over social relationships between people and firms: firms may choose business partners based on trust, social networks or goodwill rather than on price (Sturgeon, 2009: 120). In connection with this, GVC analysis developed and expanded the framework of what Gereffi had called governance. Whereas Gereffi's GCC framework had focused on the drivers of chains (for example buyer vs producer-driven chains) the GVC framework developed a richer typology for understanding how power relations are shaped, vary and shift between different nodes in a chain (Gereffi et al., 2005). Rather than reading power relations as either stemming from the dominant downstream or the dominant upstream firm, the richer typology of GVC governance rendered visible the strategies firms deploy to negotiate power in value chains (Sturgeon, 2009).

The extent to which this new attention to sociological and political factors reshaped GVC's understanding of value is, however, limited. Gereffi et al. (2001) proposes one of the literature's few explicit definitions of value:

There are several metrics that have been used to try to assess value in global chains:

Profits. [...] The most appropriate measure is generally return on capital employed [...].

Value added. [...] Value-added shares can be calculated for different links in the chain. For example, a dress selling at $\$ 100$ in the United States might break down into $\$ 6$ going to workers, $\$ 9$ to the contractor, $\$ 22.50$ for fabric, $\$ 12.50$ for the manufacturer, and $\$ 50$ to the retailer. [...]

Price markups. [...]

(Gereffi et al., 2001: 5-6)

It can be seen that value measured in pecuniary terms remains central and therefore, read on its own, this understanding differs very little from that of GCC. There is little acknowledgement of the role that power struggles and social relations play in constituting productive relations between and within firms. Aside from this definition, the GVC literature has very little critical discussion of the concept of value and the attention paid to politics and social relations has not transferred from GVC conceptions of governance to its conceptions of value or value upgrade.

This is not to argue that all perspectives in this family of literatures rely on conventional conceptions of value, or fail to discuss the meaning of the concept. Notably, the framework of 
Global Production Networks (GPN) was developed by scholars, largely coming from geography and economic geography backgrounds, alongside and as a response to GCC. This perspective critiqued GCC's lack of acknowledgement of the importance of spatiality, and especially regional (as opposed to national) economic development and the formation of regional industrial clusters (Coe et al., 2004). While the chain analogy implies only vertical integration of firms, the concept of a network also highlights the horizontal linkages between firms in a region (Sturgeon, 2000). Some would argue that the GPN approach differs very modestly from GCC in practice, however the emphasis on spatiality is a distinct theoretical difference (Bair, 2009). The concept of value in the GPN approach is defined by Coe et al.:

Here we use the term 'value' to refer to various forms of economic rent (Kaplinsky, 1998) that can be realized through market as well as non-market transactions and exchanges. Alongside value creation through the labour process, for instance, value can take the form of technological rents by way of access to particular product or process technologies, or may be manifested as relational rents, based on inter-organizational links improving know-how transfer and collective learning. Other forms of rent identified by Kaplinsky may derive from organizational attributes, trade policy and branding.

(Coe et al., 2004: 473)

Unlike GCC authors, Coe et al. stress the multiplicity and transmutability of forms of value and emphasise that it not only relates to high-skilled productive abilities, but also encompasses a broader set of advantages and resources including: technological capabilities, social and economic links to other firms and ownership of a well-regarded brand name. Nevertheless, as will become clear below, this interpretation remains within an economistic frame.

Herod et al. (2014) make a more significant break with the dominant trend within GVC and surrounding literature of drawing upon mainstream economic or Business Studies notions of value. A focus on the distribution and handling of waste through Global Destruction Networks invites a different understanding of value by asking whether value is something that stays in products once they are consumed. The role of labour is emphasised in shaping destruction networks by reference to the classic Marxist conception of value as '“congealed labour'(Marx, 1867 [1990])' (Ibid, p. 422). Value, thus defined, can transfer from one commodity to another through recycling or modification, and does not disappear once a commodity is placed on a rubbish heap - even if the forward transfer of value often ceases there (Ibid. p. 428). However, while the notion of congealed labour is useful for understanding the afterlife and rebirth of commodities, it is possible and necessary to reconsider the notion of value even more fundamentally. In addition to understanding value as something quantitative, the argument in this article is that GVC analysis and related perspectives can benefit from bringing the politics back into value. 


\section{Value in critical Global Value Chains literature}

The critical value chain literature draws broadly on Marxist analysis to emphasise the salience of labour. As value chain literatures have grown in prominence, critical GVC scholars have intervened to broaden the literature's concerns in relation to value and upgrade. Rainnie et al. (2011: 191) called for value chains literatures to integrate labour as a central aspect of their analysis:

[I]f commodity chain analysis is about value creation, capture and enhancement, then labour, as the ultimate source of value, logically must lie at its heart and the dynamics of a labour process's modus operandi, with its contested and contradictory practices relating to the extraction (and realization) of surplus value, needs to be central to any explanation.

Taylor et al. (2013) point to the continuing 'labour "deficit"' in the GVC literature (2013), and argue that value has been so poorly defined in GVC and related literatures that the concept is often meaningless. Selwyn (2013) critiques the concept of social upgrade and highlights that GVC analysts have tended to view upgrade from a firm-centric, rather than labour-centric, perspective. In this perspective labour is understood both as a source of value, and as a class with political agency (Rainnie et al., 2011: 161; Taylor et al., 2013). The ILO's Decent Work Agenda, which has informed and influenced prevalent writing on social upgrade, does not concur with the Marxist observation that wage labour is characterised by exploitation as an objective set of relations. According to Marx, the owners of a capitalist firm appropriate surplus value from their workers by forcing the latter to work for free for a portion of the working day, as the workers create more output than they are remunerated for (Marx, 2015 [1887]; Harvey, 2010). The ILO and prevalent GVC writing on social upgrade do not classify the capitalist relationship as exploitative, and are therefore unable to fully comprehend the root cause of indecent work (Selwyn, 2013: 82).

This body of literature argues that improvements to workers' conditions often are a result of workers' struggles (Selwyn, 2013; Hedberg, 2013). Social upgrade is best thought of not as something that firm owners hand out to their workers, but rather as something that workers win through collective action:

[W]ithout arrangements that commit capital to providing benefits to labour, there is no reason why individual capitalists would choose to do so (even if they wanted to) as their actions would represent a cost, thus potentially handing competitive advantage to their rivals in the market. However, what the Decent Work Agenda and, so far, the social upgrading framework ignores, is that such institutional arrangements are themselves often outcomes of and/ or responses to real or potential struggles between capital and labour.

(Selwyn, 2013: 83) 
A similar point is made in relation to Corporate Social Responsibility (CSR) and so-called ethical value chains, which are the result of struggles carried out by workers, local organisations and social movements in regions that carry out upstream production (Puppim de Oliveira and Jordão, 2014; Hughes et al., 2014).

For these authors, value is not an apolitical or merely numerical notion, but a concept inherently linked to Marx's critique of capitalist exploitation. This can be read as a challenge to econocentrism. Questions of value, therefore, do not only relate to prices or rents, but are also the result of struggles over justice waged between workers and capitalists, and local organisations beyond the firm. Therefore a value chain must be understood not only as a series of steps in the production of a good or service, but also as a set of social relations between human beings who struggle over resources and decision-making power (Neilson and Pritchard, 2009).

Value can quite usefully be understood as a question of how work should be divided and how the resulting wealth should be distributed. Here the interconnectedness between 'things' (the economy) and 'people' (society) becomes especially palpable, as was arguably Marx's contention all along (Graeber, 2001; Henderson, 2013). Development scholars, GVC analysts included, have attempted to find expert solutions to the problems of underdevelopment and low value-added capture, but they have not always acknowledged that moving beyond economistic and totalising ways of thinking requires critiquing fundamental assumptions around what makes equitable production or a 'developed' economy.

Postdevelopment and decolonial scholars often critique modernist development projects for having aims and notions of value that imply the superiority of the urban Northern lifestyle over other ways of life (Escobar, 1995; Ziai, 2007; Vázquez, 2012). This might include aiming to get people into waged, hierarchically organised and industrialised employment instead of promoting other forms of livelihood, such as communally owned production, non-monetary exchange and gift economies (Gibson-Graham, 2007). This Northern-centric view might also mean setting high earnings or accumulation of money as central aims in development: for example, development projects may measure their success by earnings or turnovers rather than other more qualitative indicators. Furthermore, it might involve promoting the organisation of workplaces according to particular formal hierarchies rather than considering other organisational models, such as egalitarian or rotational ones (Lie, 2007). By advocating aims and models in the global South that are perceived to have 'worked' in the global North, development projects may inadvertently promote an economic and cultural Northernification of the South.

Like any postdevelopment critique, this is not to dismiss the development project of economic upgrade (Ziai, 2007). Indeed, the claim that firms in the periphery are up against a global division of labour that they must relate to, and the idea that the policy suggestions of GVC analysis can help 
them tackle it, are rather persuasive. What is problematic, however, is that upgrade in value, as conventionally understood, generally amounts to an improved ability to do well according to market criteria in particular: increased profits, and increased ability to carry out higher-skilled and highertechnology productive tasks. The tension development economists must grapple with is that, while such improvements are key in counteracting the global division of labour, they are also totalising and economistic.

What a critical reading of value shows is that questions around how people should work and distribute resources cannot be determined by any neutral arbiter or expert. Whether predictions are based on a person's position in a social structure, or on universalising assumptions about human nature, their interests cannot be understood as being driven by an abstract set of behavioural rules (Granovetter, 1985). Hence, value becomes an open question - a question that is subject to political debate. This question concerns the purpose and justice of productive activity, which are not selfevident and cannot be determined by apolitical experts.

\section{Value as voice}

To summarise the argument so far: GVC analysis has, despite its sophisticated conception of chain governance and related power struggles, often adhered to economistic assumptions in its conceptions of value. A more critical look at value, however, shows that this concept must be understood as a political one; a concept that refers to the purpose and justice of human productive activity. This section will seek to add to and enrich the critical literature on value in GVC by outlining the argument that value overlaps with questions of political decision-making and voice: since value is a political concept, its meaning should be negotiated through political dialogue or struggle, rather than be assumed to be apolitical and narrowly economistic. Definitions of value, which values should be promoted and how (economic) improvement or development should be understood are in this view open to negotiation. Seen in this light, value chain upgrade becomes, not only about upgrading Southern firms' ability to carry out higher 'value-added' tasks in the global division of labour, but also about upgrading the ability of actors in a value chain to question modernist assumptions about successful production and distribution (Icaza and Vázquez, 2013). The values expressed in open negotiations may surprise and confuse modern economic scientists as success is not always defined as being competitive, indulging in conspicuous consumption or climbing the social hierarchy (Kusch, 2010: 8-14; Vázquez, 2012; Waldmüller, 2014).

Questions regarding the participation and influence of people along the value chain are by no means foreign to GVC analysis. Since its inception, GVC analysis has paid attention to chain governance. Although several studies have found that certain types of chain governance tend to be more 
beneficial for firms in the global South than other types of governance - namely more committed and less competitive ones, rather than market-based structures (see Humphrey and Schmitz, 2000; Pimbert et al., 2001) - GVC analysts rarely connect analyses of governance to analyses of upgrade. One notable exception is Bolwig et al. (2011), who cite 'Improv[ing] value chain coordination' as an upgrading strategy for small agricultural producers (:36). Producers can "'get [...] a better deal" through closer and longer-term business ties with buyers' (:36). In their seminal article on social upgrading, Barrientos et al. list some examples of what may constitute such upgrade:

for example, [when] a worker that has acquired skills in one job is able to move [to] a better job elsewhere in a GPN [...] [improvements in] category of employment (regular or irregular), wage level, social protection and working hours [...,] the percentage of women supervisors or the percentage of union members in the workforce [..., freedom of association and the right to collective bargaining, non-discrimination, voice and empowerment.

(2011: 7, emphasis added)

Both of Bolwig et al and Barrientos make a useful contribution, but their suggestions for 'voice' are not fully elaborated. In light of decolonial critiques of value, however, these undeveloped insights can be expanded to include improved governance and voice and empowerment as a form of upgrade. An increased capacity for inclusive negotiations within the value chain amounts to what we might call 'voice upgrade'. Such upgrade would refer to improved formal and informal infrastructure for discussing and negotiating the purpose and fairness of production. More specifically, voice upgrade would concern the ability of people in the value chain to take part in decisions regarding who should do what work, how remuneration and resources should be distributed, and the purpose for which productive activity should be carried out, as well as wider considerations of progress and development. Voice upgrade could thus be understood as an improvement in the democratic governance of firms and chains.

As the critical literature on value chains has shown, input from workers often become formalised through organisations such as trade unions (Selwyn, 2013; Puppim de Oliveira and Jordão, 2014). The existence and democratic functioning of trade unions would be one key concern related to voice upgrade, but one might also argue that formal and constitutional democratic governance within a firm, accompanied by worker ownership of a firm, constitutes an even better institutional setting for voices to be exchanged on equal terms (Gradin, 2015; Gibson-Graham, 2006b). Furthermore, institutional tools enabling negotiations of value across nodes in the chain are also key. Relationships across firms that provide an infrastructure for negotiating, not only the conventional issues of trade unions, but also broader questions around the aims, purpose and fairness of production. The extent to which people in a value chain have a voice on value, and the extent to which any given initiative amounts to an improvement of their ability to influence decision-making, could be studied in a manner similar to existing work on social and economic 
upgrade.

Voice upgrade, then, causes us to reject economistic conceptions of value and to broaden it to include wider issues of democracy and voice in production decisions. An analysis wherein value is understood as voice is likely to interpret an organisational setup that provides formal and informal infrastructures for participants to negotiate value (for example, a democratically organised workers' co-operative that offers all staff regular training in egalitarian democratic procedures) as more upgraded than one that does not. Rather than assuming that value universally equates to increased wealth measured in pecuniary terms at the firm level, a voice-sensitive perspective opens up the possibility of other options.

\section{Conclusion}

This article has critiqued assumptions of value prevalent in GVC analysis. A non-economistic and non-totalising reading of the concept renders value to be a political and contested notion subject to democratic negotiation. In order to challenge colonial and exploitative tendencies in global economics, GVC analysts and other development scholars must be prepared to challenge some of the deepest-held beliefs and assumptions of mainstream economic and Business Studies literature (Kusch, 2010).

That there is a pattern in the global economy whereby some regions and firms carry out higherskilled, higher-tech and higher-return productive tasks than others remains a problem. What GVC analysis has not grappled with, however, is that the notion of economic upgrade remains within a market driven and Western epistemological frame. If value is read critically, it emerges as a political concept concerning the contested nature of work and its remuneration - or more broadly, the justice and purpose of productive activity.

This article has argued that GVC analysis can link its own ideas of value chain governance to the notion of upgrade. Rather than handling governance and upgrade as distinct concerns, it has been suggested that these should be integrateded into a new concept of voice upgrade. This concept would measure the extent to and ways in which people in value chains, most notably workers, are able to speak, listen and be heard when it comes to value. Economic and social upgrading is measured by both qualitative and quantitative improvements such as increased value-added capture, better pay, shortened working hours, better working conditions and less discrimination. The nature and extent of voice upgrade could be measured by studying formal and informal opportunities to discuss value in meetings, online discussion boards, letters, conferences etc. GVC analysts could measure both the quantitative incidence of such discussions and communication, and their 
qualitative nature and impact.

Future studies might develop and critically assess the notion of voice upgrade. Questions that present themselves include not only the definition of the concept of voice (Hirschman, 1977) and whether voice upgrade might mean different things in different contexts; but also whether economic and social upgrading helps or hinders voice upgrade; what kinds of formal and informal tools might be conducive to it (Gibson-Graham, 2006b); and indeed whether voice upgrade is the most effective analytical vehicle for its intended purpose. Either way, a decolonial critique of GVC conceptions of value show that these concerns cannot be ignored.

\section{Acknowledgements}

The author wishes to thank Jane Hardy and two anonymous reviewers for their helpful comments.

\section{References}

Anker, R., Chernyshev, I., Egger, P., Mehran, F. and Ritter, J. (2002) Measuring Decent Work with Statistical Indicators. (ILO Policy Integration Department, Statistical Development and Analysis Group, Working Paper 2) Available from http://www.ilo.org/wcmsp5/groups/public/---dgreports/--integration/documents/publication/wcms_079089.pdf.

Applebaum, R. P., Smith, D. and Christerson, B (1994) 'Commodity Chains and Industrial Restructuring in the Pacific Rim: Garment Trade and Manufacturing' in G. Gereffi and M. Korzeniewicz (eds), Commodity Chains and Global Capitalism (London: Greenwood Press), 187204.

Aristotle (2010) Rhetoric. Trans by W. Rhys Roberts, ed. By W. D. Ross (New York: Cosimo Inc).

Bair, J. (2009) 'Global Commodity Chains: Genealogy and Review' in J. Bair (ed.) Frontiers of Commodity Chain Research (Stanford: Stanford University Press), 1-34.

Barrientos, S. Gereffi, G. and Rossi, A. (2011) 'Economic and Social Upgrading in Global Production Networks: A New Paradigm for a Changing World', International Labour Review, 150 (3-4), pp. 319-340.

Blaney, D. L. and Inayatullah, N. (2010) Savage Economics: Wealth, Poverty and the Temporal 
Walls of Capitalism (London: Routledge).

Bolwig, S., Ponte, S., du Toit, A., Riisgaard, L. and Halberg, N. (2010) 'Integrating Poverty and Environmental Concerns into Value-Chain Analysis: A Conceptual Framework', Development Policy Review, 28 (2), pp. 173-194.

Bolwig, S., Ponte, S., Riisgaard, L., du Toit, A. and Halberg, N. (2011) 'A Methodology for Integrating Developmental Concerns into Value Chain Analysis and Interventions' in J. Mitchell and C. Coles (eds) Markets and Rural Poverty: Upgrading in Value Chains (London: Earthscan).

Burnham, P. (1999) 'The Politics of Economic Management in the 1990s', New Political Economy, 4 (1), pp. 37-54.

Coe, N. M., Hess, M., Yeung, H. W., Dicken, P. and Henderson, J. (2004) "Globalizing' Regional Development: A Global Production Networks Perspective', Transactions of the Institute of British Geographers, 29, pp. 468-484.

Collins, P. H. (1990) Black Feminist Thought: Knowledge, Consciousness, and the Politics of Empowerment (Boston: Unwin Hyman).

Davies, M. (2012) 'The Aesthetics of the Financial Crisis: Work, Culture, and Politics', Alternatives: Global, Local, Political, 37 (4), pp. 317-330.

Daviron, B. and Ponte, S. (2005) The Coffee Paradox: Global Markets, Commodity Trade and the Elusive Promise of Development (London: Zed Books).

Dos Santos, T. (1970) 'The Structure of Dependence', The American Economic Review, 60, pp. 231236.

Escobar, A. (1995) Encountering Development: The Making and Unmaking of the Third World (Princeton: Princeton University Press).

Gasper, D. (2004) The Ethics of Development: From Economism to Human Development (Edinburgh University Press).

Gereffi, G. (1994) 'The Organization of Buyer-Driven Global Commodity Chains: How U.S. Retailers Shape Overseas Production Networks', in G. Gereffi and M. Korzeniewicz (eds), Commodity Chains and Global Capitalism (London: Greenwood Press), 95-122. 
Gereffi, G. (1995) 'Global Production Systems and Third World Development' in B. Stallings (ed) Global Change, Regional Response: The New International Context of Development (Cambridge: Cambridge University Press), 100-142.

Gereffi, G. and Korzeniewicz, M. (1990) 'Commodity Chains and Footwear Exports in the Semiperiphery' in W. G. Martin (ed) Semiperipheral States in the World-Economy (Westport: Greenwood Press), 45-68.

Gereffi, G., Korzeniewicz, M. and Korzeniewicz, R. P. (1994) 'Introduction: Global Commodity Chains' in G. Gereffi and M. Korzeniewicz (eds), Commodity Chains and Global Capitalism (London: Greenwood Press), 1-14.

Gereffi, G., Humphrey, J., Kaplinsky, R. and Sturgeon, T. J. (2001) 'Introduction: Globalisation, Value Chains and Development', IDS Bulletin, 32 (3), pp. 1-8.

Gereffi, G., Humphrey, J. and Sturgeon, T. (2005) 'The Governance of Global Value Chains', Review of International Political Economy, 12 (1), pp. 78-104.

Gibbon, P., Bair, J. and Ponte, S. (2008) 'Governing Global Value Chains: An Introduction', Economy and Society, 37 (3), pp. 315-338.

Gibson-Graham, J. K. (2006a) The End of Capitalism (As We Knew It) (2 $2^{\text {nd }}$ ed) (London: University of Minnesota Press).

Gibson-Graham, J. K. (2006b) A Postcapitalist Politics (London: University of Minnesota Press).

Gibson-Graham, J. K. (2007) 'Surplus Possibilities: Post-Development and Community Economies' in A. Ziai (ed), Exploring Post-Development: Theory and Practice, Problems and Perspectives (London: Routledge), 145-162.

Gibson-Graham, J. K. (2008) 'Diverse Economies: Performative Practices for 'Other Worlds", Progress in Human Geography, 32 (5), pp. 613-632.

Global Value Chains Initiative (2016) Concept \& Tools (Center on Globalization, Governance and Competitiveness, Duke University) Available from https://globalvaluechains.org/concept-tools.

Graeber, D. (2001) Toward An Anthropological Theory of Value: The False Coin of Our Own Dreams (Basingstoke: Palgrave). 
Gradin, S. (2015) 'Radical Routes and Alternative Avenues: How Cooperatives Can Be Noncapitalist', Review of Radical Political Economics, 47 (2), pp. 141-158.

Granovetter, M. (1985) 'Economic Action and Social Structure: The Problem of Embeddedness', American Journal of Sociology, 91 (3), pp. 481-510.

Harvey, D. (2010) A Companion to Marx's Capital (London: Verso).

Hedberg, C. (2013) "'Grapes of Wrath"? Power Spatialities and Aspects of Labour in the Wild Berry Global Commodity Chain', Competition and Change, 17 (1), pp. 57-74.

Henderson, G. (2013) Value In Marx: The Persistence of Value in a More-Than-Capitalist World (Minneapolis: University of Minnesota Press).

Herod, A. (2001). 'Implications of Just-in-Time Production for Union Strategy: Lessons from the 1998 General Motors-United Auto Workers Dispute', Annals of the Association of American Geographers, 90 (3), pp. 521-547.

Herod, A., Pickren, G. Rainnie, A. and McGrath Champ, S. (2014) 'Global Destruction Networks, Labour and Waste', Journal of Economic Geography, 14 (2), pp. 421-441.

Hirschman, A. O. (1977) The Passions and the Interests: Political Arguments for Capitalism Before Its Triumph (Princeton, NJ: Princeton University Press).

Hughes, A., McEwan, C., Bek, D. and Rosenberg, Z. (2014) 'Embedding Fairtrade in South Africa: Global Production Networks, National Initiatives and Localized Challenges in the Northern Cape', Competition and Change, 18 (4), pp. 291-308.

Humphrey, J. and Schmitz, H. (2000) Governance and Upgrading: Linking Industrial Cluster and Global Value Chain Research, University of Sussex Institute of Development Studies Working Paper 120. Available from http://biblioteca.fstandardbank.edu.ar/images/e/e6/Clusters_11.pdf.

Humphrey, J. and Schmitz, H. (2002) 'How Does Insertion in Global Value Chains Affect Upgrading in Industrial Clusters?, Regional Studies 36 (9), pp. 1017-2002.

Icaza, R and Vázquez, R. (2013) 'Social Struggles as Epistemic Struggles', Development and Change, 44 (3), pp. 683-704.

Kaplinsky, R. (1998) Globalisation, Industrialisation and Sustainable Growth: The Pursuit of The 
Nth Rent, Institute of Development Studies Discussion Paper 365. Available from https://www.ids.ac.uk/files/Dp365.pdf.

Kimmell, M. (1994) 'Masculinity as Homophobia' in H. Brod and M. Kaufman (eds), Theorizing Masculinities (London: Sage), 119-141.

Kusch, R. (2010) Indigenous and Popular Thinking in América. Trans by M. Lugones and J. Price (Durham: Duke University Press).

Lie, J. H. S. (2007) 'Post-Development and the Discourse-Agency Interface' in A. Ziai (ed), Exploring Post-Development: Theory and Practice, Problems and Perspectives (London: Routledge), 47-62.

Lund-Thomsen, P. and Wad, P. (2014) 'Global Value Chains, Local Economic Organization and Corporate Social Responsibility in the BRICS Countries', Competition and Change, 18 (4), pp. 281290.

Marx, K. (2015 [1887]) Capital: A Critique of Political Economy. Volume I. Available from http://www.marxists.org/archive/marx/works/1867-c1/.

Mignolo, W. (2007) 'DELINKING: The Rhetoric of Modernity, the Logic of Coloniality and the Grammar of De-coloniality', Cultural Studies, 21 (2-3), pp. 449-514.

Mignolo, W. (2011) The Darker Side of Western Modernity: Global Futures, Decolonial Options (Durham: Duke University Press).

Mignolo, W. and Escobar, A. (2010) (eds) Globalization and the Decolonial Option (New York: Routledge).

Milberg, W. and Winkler, D. (2010) Economic and Social Upgrading in Global Production Networks: Problems of Theory and Measurement, Capturing the Gains Working Paper 4. Available from http://www.capturingthegains.org/publications/workingpapers/wp_201004.htm.

Morrison, A., Pietrobelli, C. and Rabellotti, R. (2008) 'Global Value Chains and Technological Capabilities: A Framework to Study Learning and Innovation in Developing Countries', Oxford Development Studies, 36 (1), pp. 39-58.

Neilson, J. and Pritchard, B. (2009) Value Chain Struggles: Institutions and Governance in the Plantation Districts of South India (Chichester: Blackwell/John Wiley and Sons). 
Pimbert, M. P., Thompson, J., Vorley, W. T., Fox, T., Kanji N. and Tacoli, C. (2001) Global Restructuring, Agri-Food Systems and Livelihoods, International Institute for Environment and Development, Gatekeeper Series No. 100. Available from http://pubs.iied.org/pdfs/9166IIED.pdf.

Pocock, J. G. A. (1985) 'The Mobility of Property and the Rise of Eighteenth-Century Sociology' in J. G. A. Pocock, Virtue, Commerce and History (Cambridge: Cambridge University Press), 103123.

Porter, M. (1985) Competitive Advantage: Creating and Sustaining Superior Performance (New York: Free Press).

Puppim de Oliveira, J. A. and Jordão, P. (2014) 'Global Value Chains and Social Upgrading of Clusters: Lessons from Two Cases of Fair Trade in the Brazilian Northeast', Competition and Change, 18 (4), pp. 365-381.

Quijano, A. (2007) 'Coloniality and Modernity/Rationality', Cultural Studies, 21 (2-3), pp. 168-178.

Rainnie, A., Herod, A. and McGrath-Champ, S. (2011) 'Review and Positions: Global Production Networks and Labour', Competition and Change, 15 (2), pp. 155-169.

Ramiro Fernández, V. (2015) 'Global Value Chains in Global Political Networks: Tool for Development or Neoliberal Device?' Review of Radical Political Economics, 47 (2), 209-230.

Schmitt, R. (2010) Schmitt: The End of Capitalism. Available from http://marxandphilosophy.org.uk/reviewofbooks/reviews/2010/74.

Selwyn, B. (2013) 'Social Upgrading and Labour in Global Production Networks: A Critique and an Alternative Conception', Competition and Change, 17 (1), pp. 75-90.

Smith, A. (1976) [1776] An Inquiry into the Nature and Causes of the Wealth of Nations (University of Chicago Press).

Sturgeon, T. (2000) How Do We Define Value Chains and Production Networks?, Background Paper Prepared for the Bellagio Value Chains Workshop. Available from https://www.ids.ac.uk/ids/global/pdfs/vcdefine.pdf.

Sturgeon, T. (2009) 'From Commodity Chains to Value Chains: Interdisciplinary Theory Building in an Age of Globalization' in J. Bair (ed) Frontiers of Commodity Chain Research (Stanford, California: Stanford University Press), 110-135. 
Taylor, P. (2010) 'The Globalization of Service Work: Analysing the Transnational Call Centre Value Chain' in P. Thompson and C. Smith (eds) Working Life: Renewing Labour Process Analysis (Basingstoke: Palgrave Macmillan), 244-268.

Taylor, P., Newsome, K. and Rainnie, A. (2013) "'Putting Labour in its Place": Global Value Chains and Labour Process Analysis', Competition and Change, 17 (1), pp. 1-5.

Trienekens, J. H. (2011) 'Agricultural Value Chains in Developing Countries: A Framework for Analysis', International Food and Agribusiness Management Review, 14 (2), pp. 51-82.

Vázquez, R. (2012) 'Towards a Decolonial Critique of Modernity: Buen Vivir, Relationality and the Task of Listening', in R. Fornet-Betancourt (ed), Capital, Poverty, Development, Denktraditionen im Dialog Vol 33. Available from http://www.ceapedi.com.ar/imagenes/biblioteca/libros/241.pdf.

Waldmüller, J. (2014) Buen Vivir, Sumak Kawsay, 'Good Living': An Introduction and Overview. Available from http://www.alternautas.net/blog/2014/5/14/buen-vivir-sumak-kawsay-good-livingan-introduction-and-overview.

Wallerstein, I. (1974) The Modern World-System: Capitalist Agriculture and the Origins of the European World-Economy in the Sixteenth Century (New York: Academic Press).

Zein-Elabdin, E. O. and S. Charusheela (2004) (eds) Postcolonialism Meets Economics (London: Routledge).

Ziai, A. (2007) 'Development Discourse and Its Critics: An Introduction to Post-Development', in A. Ziai (ed) Exploring Post-Development: Theory and Practice, Problems and Perspectives (London: Routledge), pp. 3-17. 